\title{
КРИТЕРІЇ СУЧАСНОСТІ ЛЕКЦІЇ З ФІЗІОЛОГІЇ
}

\author{
В. О. Куровська
}

Національний медичний університет імені О. О. Богомольця

CRITERIA OF MODERNITY FOR PHYSIOLOGY LECTURES

V. O. Kurovska

\section{O. Bohomolets National Medical University}

\begin{abstract}
У статті розглядається питання, яким критеріям повинна відповідати сучасна лекція з фізіології. Тенденція, яка спостерігається у світі, полягає в тому, щоб за допомогою сучасних мультимедійних технологій перетворити аудиторію із пасивних слухачів на активних учасників лекційного процесу. Вивчаючи дану проблему, серед студентів було проведено анкетування з метою встановити, якою вони бачать сучасну лекцію. За його результатами виходить, що вони відкидають ідею про те, що дистанційна чи записана і рекомендована до перегляду лекція може замінити класичну. Згідно зі студентською думкою, сучасність лекції визначається професіоналізмом лектора, його обізнаністю з новими досягненнями науки та вмінням вдало розкрити тему. На лекціях з фізіології доцільно демонструвати відеофільми 3 експериментами над тваринами.
\end{abstract}

The article considers the matter of the criteria for the modern physiology lecture. A tendency observed in the modern world lies in the fact that advanced multimedia technologies are supposed to help to transform the audience from passive listeners into active participants of learning process. Some students were surveyed with a porpose to estimate how they watch the modern lecture. The results show that they reject the idea that a distant lecture or the one recorded and recommended for watching could replace the classic lecture. According to the students, the modernity of the lecture is determined by the lector's professionalism, his or her awareness of new science achievements and ability to uncover the topic successfully. Lectures on physiology are to be accompanied by videos demonstrating experiments on animals.

Вступ. На сьогодні питання про доцільність лекції, як невід’ємної частини навчального процесу, вже майже не дискутується. Навпаки, викладачі усього світу шукають шляхи вдосконалення цього виду педагогічної діяльності. Основна концепція полягає у тому, щоб перетворити студента із пасивного слухача на активного учасника пізнавального процесу. Вдале використання мультимедійних технологій - це ще один спосіб зробити навчання більш цікавим та ефективним.

У свою чергу, така дисципліна, як фізіологія, розвивалась і сприймається як експериментальна наука. Завданням iï $€$ поєднання сучасних форм подачі інформації та збереження експерименту як необхідної складової.

Основна частина. Сучасною, в першу чергу, вважають лекцію, яка включає у собі презентацію. Це, безперечно, полегшує висвітлення матеріалу, дозволяє зробити його наочним. Однак, якщо розглядати презентацію тільки як засіб, що допомагає

\footnotetext{
(C) В. О. Куровська
}

викладачу, вона не змінить їі суті. Тобто лекція залишиться монологом. Використання презентації повинно допомогти активізувати аудиторію. За ії допомогою нову тему можна розпочинати з проблеми, запитань, ситуацій, на які студенти не знають відповіді. А далі поступово висвітлювати їх. Таким чином, слідкуючи за думкою, студенти активно залучаються до педагогічного процесу, знаходять пояснення для раніше невідомого [1].

Неодноразово висловлювалась думка, що те, як ми вчимо, набагато важливіше від того, що ми вчимо. Зауважується, що будь-яку інформацію, навіть якщо вона повторює підручник, можна викласти цікаво, зробити її емоційно забарвленою [2, 3].

Загалом, метою удосконалень, які впроваджують викладачі, є забезпечення того, щоб час, проведений на лекціях, був максимально ефективним. Ці нововведення дещо змінюють перебіг лекції, роблять ї̈, так званою, нетрадиційною.

Варіанти лекцій, у тому числі нетрадиційних, детально описані та узагальнені [4]. Серед інших 
способів удосконалення подачі матеріалу пропонуються наступні.

Невеликі перерви, під час яких студенти відповідають на тестові запитання, роздані їм у паперовій формі [5]. Письмові контрольні роботи по темі після лекції у вигляді домашнього завдання, яке потім підлягає перевірці [6]. Короткі комп’ютерні ігри під час лекції для збереження уваги студентів та активного залучення їх до навчального процесу [7]. Розміщення лекційного матеріалу (слайди 3 синхронним звуком) на сайті кафедри із можливістю надсилання запитань через e-mail [8].

Для забезпечення зворотного зв’язку з аудиторією навіть було винайдено спеціальний пристрій, названий авторами пристроєм індивідуальної системи відповідей [9]. Шляхом натискання на розташовані на панелі кнопки студенти відповідають на запитання, поставлені їм у ході лекції. Можливі декілька систем відповідей: правильно/неправильно, порядковий номер, буквене позначення. Студенти бачать відповідь, яку вони вибрали на дволінійному дисплеї, а також те, що вона прийнята. Результати відповідей автоматично з’являються на дисплеї у викладача у вигляді гістограми або вираженими у відсотках правильних та неправильних відповідей.
Це дозволяє одразу корегувати подачу матеріалу, зупиняючись на незрозумілих моментах.

Заслуговує на увагу так звана стендова лекція, тобто розміщення навчальної інформації на стендах у період вивчення певної теми [10]. Студенти мають можливість декілька разів переглянути матеріал, поданий у стислій, гарно ілюстрованій формі під час перерви, після занять або й, навіть, мимовільно. Безумовно, така форма подачі навчального матеріалу позитивно вплине на його осмислення та запам’ятовування.

Розмірковуючи над даною темою, не може не виникнути запитання, якою ж бачать сучасну лекцію самі студенти. 3 цією метою було проведено анкетування, в якому взяли участь 262 студенти другого курсу навчання лікувального, стоматологічного та педіатричного факультетів, не включаючи англомовних. В анкеті пропонувалося вибрати певні твердження зі списку. Останні можна об’єднати у три групи. Чи потрібні лекції за наявності сучасних технологій? Наскільки лекція залежить від лектора? Чи повинні на лекціях з фізіології демонструватись експерименти над тваринами? У таблиці 1 наведено виражений у відсотках результат проведеного опитування.

Таблиця 1. Результати анкетування серед студентів 2-го курсу за темою “Якою повинна бути сучасна лекція з фізіології?”

\begin{tabular}{|c|l|c|}
\hline № & \multicolumn{1}{|c|}{ Твердження, які набрали максимальний відсоток } & $\%$ \\
\hline 1 & $\begin{array}{l}\text { Лекція залежить від лектора, можна не перетворювати ії на нудне конспектування, а цікаво розповісти мате- } \\
\text { ріал, час від часу переключаючи увагу студентів поясненням малюнків з презентації чи показуванням відео }\end{array}$ & 88 \\
\hline 2 & Лекції необхідні для того, щоб викладач доводив до аудиторії сучасні нові дані, яких немає у книжках & 68 \\
\hline 3 & $\begin{array}{l}\text { Вміння читати лекції - це дар, серед викладачів має проводитись конкурс і лекторами мають бути } \\
\text { лише деякі люди, тоді студенти будуть слухати лекції }\end{array}$ & 63 \\
\hline 4 & $\begin{array}{l}\text { Новий матеріал з фізіології обов’язково має підкріплюватись дослідами, однак немає необхідності } \\
\text { знущатися над тваринами, лектор може показувати експеримент на відео }\end{array}$ & 61 \\
\hline & \multicolumn{1}{|c|}{ Твердження, які набрали проміжний відсоток } \\
\hline 5 & $\begin{array}{l}\text { Під час лекції має бути живе спілкування викладача і студента (не презентація), викладач має працю- } \\
\text { вати на дошці, а аудиторія в зошиті і у голові, разом розбирати те, що незрозуміло }\end{array}$ & 50 \\
\hline 6 & $\begin{array}{l}\text { Перед лекцією студенту мають роздаватися заготовки для конспектування, де наявна певна частина } \\
\text { лекційного матеріалу (план лекції, малюнки, схеми), а іншу частину студент заповнює самостійно під } \\
\text { час конспектування }\end{array}$ & 42 \\
\hline 7 & $\begin{array}{l}\text { На лекціях з фізіології мають демонструватися експерименти над тваринами, лектор має підкріплю- } \\
\text { вати новий матеріал показовими дослідами }\end{array}$ & 37 \\
\hline 8 & $\begin{array}{l}\text { Лекції необхідні, оскільки дають вербальні навички, стандарт усної професійної мови (наприклад, як } \\
\text { правильно вимовляти терміни) }\end{array}$ & 27 \\
\hline & \multicolumn{2}{|c|}{ Твердження, які набрали мінімальний відсоток } \\
\hline 9 & \begin{tabular}{l} 
Лекції не потрібні, оскільки на 90 \% увесь лекційний матеріал є в підручниках \\
\hline 10
\end{tabular} & Дистанційна лекція неможлива, оскільки у деяких студентів низька самодисципліна \\
\hline 11 & $\begin{array}{l}\text { Лекції мають бути інтерактивними, у вигляді дистанційного навчання, а викладач має контролювати, } \\
\text { чи передивився студент його лекцію чи ні }\end{array}$ & 8 \\
\hline 12 & $\begin{array}{l}\text { Немає необхідності показувати експерименти, зовнішня робота органів - це очевидні речі, завдання } \\
\text { сучасної фізіології - пояснити складні механізми, за якими вона відбувається }\end{array}$ & 1 \\
\hline
\end{tabular}


Як видно з наведених результатів, студенти хочуть бачити перед собою, у першу чергу, висококваліфікованого викладача, який вільно володіє матеріалом та вміє майстерно розкрити його перед аудиторією. Бути пасивними слухачами не подобається і самим студентам. Відносно дистанційної лекції, як про її доцільність, так і про неможливість було набрано приблизно однаковий відсоток голосів. В обох випадках він був мінімальним від загальної кількості. Це ж стосується твердження про те, що лекції не потрібні.

Над вибраними твердженнями потім необхідно було зазначити порядок їх значимості: 1-ше, 2-ге та 3-тє місце. Перше та друге місця студенти віддали твердженню про те, що лекція залежить від лектора. Це положення поставили на 1-ше місце 38 \% студентів та 25 \% - на 2-ге. Частина вважає, що на першому місці має бути конкурсна основа для викладачів, які читають лекції (14 \%), і 13 \% те, що матеріал з фізіології обов’язково має підкріплюватись експериментами на відео. Це ж твердження 18 \% студентів поставили на друге місце. На цьому ж місці 15 \% отримало твердження про необхідність сучасних нових даних на лекціях. На третьому місці це твердження набрало найбільший відсоток голосів (15 \%), далі: про конкурсну осно-

\section{Список літератури}

1. Ковальчук О. Л. Проблемно орієнтована лекціяконференція з елементами випереджаючого навчання та візуалізації за темою “Синдром абдомінального болю у дітей” у додипломній підготовці лікарів / О. Л. Ковальчук // Медична освіта. - 2015. - № 1. - С. 55-59.

2. Bradbury N. A. Attention span during lectures: 8 seconds, 10 minutes, or more? / N. A. Bradbury // Advances in physiology education. - 2016. - Vol. 40, № 4. - Р. 509-513.

3. Масний 3. П. Нові підходи до читання лекцій один із шляхів вдосконалення навчального процесу / 3. П. Масний // Медична освіта. - 2004. - № 3-4. C. $15-17$.

4. Заморський I. I. Значення лекції як вагомого пізнавально-виховуючого фактора у підготовці майбутнього медичного працівника / I. I. Заморський, Т. В. Хмара // Медична освіта. - 2016. - № 1. - С. 70-73.

5. Ghorbani A. Using paper presentation breaks during didactic lectures improves learning of physiology in undergraduate students / A. Ghorbani, K. Ghazvini // Advances in physiology education. - 2016. - Vol. 40, № 1. - P. 93-97. ву у читанні лекцій (13 \%) та підкріплення нового матеріалу експериментами на відео (13 \%).

Дані проведеного опитування свідчать про те, що студенти, хоча й часто їм не відповідають, все ж орієнтуються на високі стандарти, прагнуть забезпечення якісної освіти. 3 іншого боку, очевидно, що лекції потрібні не тільки студентам, але і викладачам, оскільки це запорука їх роботи над собою, а отже, і професійного розвитку.

Лекція для викладача - це його обличчя, можливість, якщо не джерело, постійного вдосконалення. Лекція - це показник професіоналізму кожного із нас. За вмінням читати лекції стоїть постійна праця та любов до свого предмета, які є запорукою сучасності кожної лекції.

Висновки: 1. Сучасність кожної лекції, та з фізіології зокрема, визначається кваліфікованістю самого лектора, є відображенням його професійної досконалості.

2. Сучасні технології дозволяють демонструвати експерименти на відео, що дає можливість фізіології залишатись експериментальною наукою, обмежувати використання гострого експерименту, в такий спосіб слідувати світовим гуманним тенденціям по відношенню до тварин.

6. Qureshi A. Combination of didactic lectures and review sessions in endocrinology leads to improvement in student performance as measured by assessments / A. Qureshi, C. Cozine, F. Rizvi // Advances in physiology education. 2013. - Vol. 37, № 1. - P. 89-92.

7. Bhaskar A. Playing games during a lecture hour: experience with an online blood grouping game / A. Bhaskar // Advances in physiology education. - 2014. - Vol. 38, № 3. - P. 277-278.

8. Horton D. M. Assessment outcome is weakly correlated with lecture attendance: influence of learning style and use of alternative materials / D. M. Horton, S. D. Wiederman, D. A. Saint // Advances in physiology education. - 2012. Vol. 36, № 2. - P. 108-115.

9. Promoting student-centered active learning in lectures with a personal response system / S. A. Gauci, A. M. Dantas, D. A. Williams [et al.] // Advances in physiology education.2009. - Vol. 33, № 1. - P. 60-71.

10. Чулак Л. Д. Стендові лекції як засіб активізації самостійної роботи студентів / Л. Д. Чулак, А. О. Бас, В. Г. Шутурмінський // Медична освіта. - 2010. - № 1. C. 93-96. 